\title{
Erratum to: Comparison of physicochemical traits of dry-cured ham from purebred Berkshire and crossbred Landrace $\times$ Yorkshire $\times$ Duroc (LYD) pigs
}

\author{
Dong-Gyun Yim ${ }^{1}$, Jong-Hyun Jung ${ }^{2}$, Md. Mahabbat Ali ${ }^{3}$ and Ki-Chang Nam ${ }^{3 *}$ \\ ${ }^{1}$ Department of Animal Science, Sangji University, Wonju 26339, Korea \\ ${ }^{2}$ Senior Director, Jung P\&C Institute, Inc., Yongin 16950, Korea \\ ${ }^{3}$ Department of Animal Science and Technology, Sunchon National University, Sunchon 57922, Korea
}

\section{Erratum}

In the published article "Comparison of physicochemical traits of dry-cured ham from purebred Berkshire and crossbred Landrace $\times$ Yorkshire $\times$ Duroc (LYD) pigs. J Anim Sci Technol 2019;61(1):3540. https://doi.org/10.5187/jast.2019.61.1.35," the author's name is given incorrectly. The spelling of Md. Mahabbat Ali's name was incorrectly given as Md. Mhahbbat Ali. The editorial office would like to correct the author's name.

\section{ORCID}

Dong-Gyun Yim https://orcid.org/0000-0003-0368-2847

Jong-Hyun Jung

Md. Mahabbat Ali https://orcid.org/0000-0003-3667-7710 https://orcid.org/0000-0002-5332-7758

Ki-Chang Nam https://orcid.org/0000-0002-2432-3045

\section{References}

1. Yim DG, Jung JH, Ali MM, Nam KC. Comparison of physicochemical traits of dry-cured ham from purebred Berkshire and crossbred Landrace $\times$ Yorkshire $\times$ Duroc (LYD) pigs.J Anim Sci Technol. 2019;61:35-40.

\footnotetext{
Corresponding author: Ki-Chang Nam, Department of Animal Science \& Technology, Sunchon National University, Suncheon 57922, Korea.
} Tel: +82-61-750-3231, E-mail: kichang@scnu.kr

This is an Open Access article distributed under the terms of the Creative Commons Attribution Non-Commercial License (http://creativecommons.org/licenses/by$\mathrm{nc} / 4.0 /$ ) which permits unrestricted non-commercial use, distribution, and reproduction in any medium, provided the original work is properly cited.

Copyright (C) 2019 Korean Society of Animal Science and Technology. 
